\title{
Evaluation of Open-end Funds Performance Using DEA Model and Analysis of Their Impacts - Empirical Evidence from China
}

\author{
Beibei Yan, Maoguo Wu*
}

SILC Business School, Shanghai University, Shanghai, China 20 Chengzhong Road, Jiading District, Shanghai, 201899, China

DOI: $10.36348 /$ sjef.2020.v04i06.010 $\quad$ | Received: 31.05 .2020 | Accepted: 08.06.2020 | Published: 12.06 .2020

*Corresponding author: Maoguo $\mathrm{Wu}$

\section{Abstract}

In this paper, we use data envelopment analysis (DEA) to evaluate the relative performance of 41 open-end funds from 2015 to 2018 in China market. By comparison, it is found that the traditional performance measurement index based on investment return rate and DEA model have both similarities and differences in evaluating relative performance of fund. The fund performance evaluation system established by DEA model includes many estimators such as risk reward, fund behavior and growth liquidity. It could accomplish more comprehensive performance evaluation results than traditional performance analysis methods. In addition, this paper uses DEA-Malmquist super-efficiency to analyze the potential micro and macro factors that influence the relative performance of fund. The result shows that there may be an optimal interval between relative performance of fund and its size. The current investors of open-end funds are mainly small and medium-sized investors and the participation of institutional investors is low. Increasing the percentage of institutional investors could have a positive impact on the fund's relative performance. This paper brings perspectives and suggestions for investors, fund managers and market supervisors to further improve the efficiency of open-end fund and its relative performance.

Keywords: Fund Performance; Super-efficiency DEA Model; Mlamquist Index; Influence factors.

Copyright @ 2020: This is an open-access article distributed under the terms of the Creative Commons Attribution license which permits unrestricted use, distribution, and reproduction in any medium for non-commercial use (NonCommercial, or CC-BY-NC) provided the original author and source are credited.

\section{INTRODUCTION}

In the 1960s, after the establishment of traditional evaluation frameworks such as CAPM, Sharpe Index and Treynor Index, the performance evaluation of securities investment fund mainly focuses on the excess return and the impact after removing nonsystematic risk. It plays an important role in guiding the development of securities investment funds and investors. Treynor first proposed the excess return rate after the non-systematic risk was effectively dispersed in 1965[14]. Sharpe proposed the excess return index adjusted by volatility risk in 1966. Jesesn proposed Jesen Alpha using adjusted excess return on market risk as an evaluation indicator in 1968. The above three indexes have become the prevailing method of performance evaluation of securities investment funds. After that, Fama three-factor model was established on the basis of CAPM in 1992, and soon developed into a five-factor model for forecasting investment return (joined with bond maturity and risk premium). Furthermore, the model including capabilities of fund manager (timing and stock selection) is also being studied. However, the traditional fund performance evaluation model is mostly based on the strict premise and hypothesis of CAPM model or APT and so on. These assumptions may not be satisfied in the real financial market that resulting in distorted evaluation results. In addition, the traditional fund performance evaluation model has the potential problem of single index, and its evaluation system focuses on the riskreturn dimension, which cannot reflect the efficiency of resource input and output in fund management. As a result, at the end of last century, more performance evaluation models such as genetic algorithm, neural network and data envelopment analysis (DEA) were put forward one after another.

DEA model, also known as data envelopment analysis, is a non-parametric evaluation method proposed by Charnes in 1978[13] which has been widely used in economics and other fields. The model adopts the method of linear programming approach to measure the performance in the form of input and output. More and more scholars apply DEA to the evaluation of fund performance [1-6]. Wu and Song [7] point out that the operation time of fund in China market is short and the systematic risk is big. Using the rate of return only as the index the fund performance is 
very unstable. It is important for the regulators of securities investment funds to realize that using DEA index could aggregate many input-output indexes such as fund control, liquidity and market fundamentals etc.

\section{Dea Model}

The DEA method is based on linear programming, and the relative efficiency of decisionmaking units (we use DMU as abbreviation, in this paper DMU represents the individual of each open-end fund) is evaluated by adopting multiple input indexes and multiple output indexes. Keeping the input and output indexes of DMUs unchanged, an effective production frontier is determined by linear programming. On this basis, each DMU unit is projected to the production front, and the degree of deviation from the front surface is calculated to determine the relative effectiveness of DMU.

DEA model is developed from its original CCR model from 1978. The model assumes there are $n$ DMUs and each DMUs contain $m$ types of input indicators.

$$
\operatorname{Maxh}_{\mathrm{jo}}=\frac{\sum_{\mathrm{r}=1}^{\mathrm{s}} \mathrm{u}_{\mathrm{r}} \mathrm{y}_{\mathrm{rjo}}}{\sum_{\mathrm{i}=1}^{\mathrm{m}} \mathrm{v}_{\mathrm{i}} \mathrm{x}_{\mathrm{ijo}}}
$$

$$
\begin{aligned}
& \text { s.t. } \frac{\sum_{r=1}^{s} u_{r} y_{r j}}{\sum_{i=1}^{m} v_{i} x_{i j}} \leq 1, \quad j=1,2, \ldots \ldots n, \quad u \geq 0, v \geq 0 \\
& x_{i j} \text { Represents the input value of the } j \text { DMU in Project } i \\
& y_{r j} \text { Represents the output value of the } j \text { DMU in Project } r \\
& v_{i}, u_{r} \text { Represents the weights for input item } i \text { and output item } r \\
& h_{j} \text { Represents the relative efficiency of the } J \text { DMU }
\end{aligned}
$$

The Common DEA model limits the relative efficiency of each DMU $(\mathrm{Hj})$ between 0 and 1 , finds the best weight for DMU efficiency value according to the set of feasible solutions of each DMU vi and ur, maximizes the efficiency of J DMU. Each DMU applies the limit function that produces $\mathrm{n}$ linear programming results under the same constraint conditions. The DMU efficiency values obtained by this method are therefore relative efficiency and can be compared with each other. On this basis, DEA model is presented as Fractional Programming, which leads to the possibility of infinite solutions. Therefore, Carnes [13] revises the model as Linear Programming to facilitate computation.

In the traditional DEA model, the DMU which falls on the efficient frontier is considered to be the efficient DEA with a DEA value of 1 . However in the actual evaluation process, there are often multiple DMU falling on the effective frontier at the same time and cannot be compared with each other. Hence, Lee et al. [15] improves the traditional DEA model and recalculates the DEA value of more than 1 from its surplus.

$$
\begin{gathered}
\operatorname{Min} \sum_{r=1}^{\mathrm{s}} \mathrm{S}_{\mathrm{r}} \text {, s.t. } \sum_{\mathrm{r}=1}^{\mathrm{s}} \mathrm{S}_{\mathrm{i}, \mathrm{r}} \lambda_{\mathrm{i}, \mathrm{j}} \mathrm{y}_{\mathrm{i}, \mathrm{r}}^{\mathrm{j}}+\mathrm{S}_{\mathrm{i}, \mathrm{r}} \lambda_{\mathrm{i}, \mathrm{j}} \mathrm{y}_{\mathrm{i}, \mathrm{r}}^{\mathrm{k}} \geq \mathrm{y}_{\mathrm{i}, \mathrm{r}}^{\mathrm{k}}, \mathrm{r}=1,2, \ldots \ldots, \mathrm{s}, \sum_{\mathrm{j}=1, \mathrm{j} \neq \mathrm{k}}^{\mathrm{n}} \lambda_{\mathrm{i}, \mathrm{j}}=1, \\
\lambda_{\mathrm{i}, \mathrm{j}} \geq 0 \mathrm{j} \neq \mathrm{k}, \mathrm{S}_{\mathrm{i}, \mathrm{r}} \geq 0 \mathrm{r}=1,2, \ldots \ldots, \mathrm{s}
\end{gathered}
$$

In the above formula, $\mathrm{S}_{\mathrm{i}, \mathrm{r}} \mathrm{y}_{\mathrm{i}, \mathrm{r}}^{\mathrm{j}}$ is the surplus part relative to DMU efficient frontier in DEA model? The efficiency of the residual DMU can be calculated if the value is not 1 after the model is deformed.

\section{Mlamquist index}

Mlamquist index reflects the change of the relative efficiency of Dmu in different periods. Malmquist index is a dynamic measure of the efficiency of DMU calculating the change of productivity of all factors over time. The basic expression is as follows:

$$
M_{i, 0}\left(X_{i, t}, Y_{i, t}, X_{i, t+\Delta t}, Y_{i, t+\Delta t}\right)=\frac{D_{i, 0}^{t+\Delta t}\left(X_{i, t+\Delta t}, Y_{i, t+\Delta t}\right)}{D_{i, 0}^{t+\Delta t}\left(X_{i, t}, Y_{i, t}\right)} \times \frac{D_{i, 0}^{t}\left(X_{i, t+\Delta t}, Y_{i, t+\Delta t}\right)}{D_{i, 0}^{t}\left(X_{i, t}, Y_{i, t}\right)}
$$

In this formula, $D_{i, 0}^{t+\Delta t}\left(X_{i, t+\Delta t}, Y_{i, t+\Delta t}\right)$, $D_{i, 0}^{t}\left(X_{i, t+\Delta t}, Y_{i, t+\Delta t}\right)$ represent the input distance function compared with effective frontier in the period, and $D_{i, 0}^{t+\Delta t}\left(X_{i, t}, Y_{i, t}\right), \quad D_{i, 0}^{t}\left(X_{i, t}, Y_{i, t}\right)$ represent the input distance function of $y$ compared with effective frontier in the same period $(t, \Delta t)$. The first part indicates the degree of change in performance over the period. A ratio greater than 1 indicates an increase of Efficiency over the period. The second part indicates a ratio of performance in two periods. Thus, Malmquist values play an important role in the dynamic analysis of fund performance evaluation.

DEA model include the multiple inputs and outputs of decision-making units. This model alleviates the distortion of evaluation results caused by the choice of different criteria. It is more comprehensive than other single-dimension models in the study of fund performance. The major advantages of Malmquist-DEA fund evaluation methods are as follows: 
1. DEA method does not require any assumption of functional relationship between input and output; it is suitable for the analysis of unknown relationship between input and output in the real financial investment market.

2. Mlamquist takes into account the change of performance. It measures the dynamic investment efficiency of fund and it can disaggregate the change process into sub components such as efficiency improvement and scale change etc.

3. DEA model uses the efficiency frontier in linear programming. Compared with the traditional parameter estimation method, its performance measure reaches the optimal value. The super-efficiency DEA model improves the technical limitation that calculates efficiency value above 1 and provides a better data basis for further analysis. It measures multiple dimension including risk return, fund behavior and liquidity etc. to provide a more comprehensive results of performance evaluation.

\section{Calculation of DEA model}

This paper selects Sharpe index and weighted net growth rate as the output indicators. Sharpe index is widely recognized as a superior traditional evaluation index by scholars. Guo[8] uses a data of China's openend fund overall years and concludes that Sharpe index is still an effective risk-return measurement index. We use Sharpe index to measure the effective return of fund. Weighted net growth rate is the net value of a security investment fund that treats the dividends of fund as reinvestment. It is used as an indicator of the long-term investment performance of fund and reflects the growth of net value within a specified period.

We use Beta value, standard deviation of return, management fee rate and change rate of fundshares as input indicators. Beta value can be used to measure the relative risk within a short period of time in the performance evaluation of fund. It reflects an adjustment of market risk in different industries corresponding to systematic risk [9]. The standard deviation of return represents the total risk faced by fund including the systematic and non-systematic risk of the whole securities market. The management fee is an expense incurred in the fund's operations. Wu et al. [10] stated that the management cost of securities investment funds is the main factor of performance measurement from investors' perspective. Finally, the change rate of fundshares reflects the trading situation of fund and the expectation of fund performance. Li and Chu [6] point out that the change rate of fundshares is positively correlated with the trading frequency. It reflects the stability of fund operation. The higher the index, the greater the volatility of Fund's position, and the higher the possible risk.

This paper adopts Malmquist value of super efficiency to calculate the super efficiency of fund under the condition of constant return of size. All input and output indicators are selected from the Wind database from 2015 to 2018 . A total of 41 open-end securities investment funds were collected. The Index results are shown in Table 1:

Table-1: DEA-Mlamquist Index

\begin{tabular}{|c|c|c|c|c|c|c|}
\hline No & DMU & $\begin{array}{l}\text { DEA- } \\
\text { Malmquist } \\
\text { index } 2015\end{array}$ & $\begin{array}{l}\text { DEA- } \\
\text { Malmquist } \\
\text { index } 2016 \\
\end{array}$ & $\begin{array}{l}\text { DEA- } \\
\text { Malmquist } \\
\text { index } 2017\end{array}$ & $\begin{array}{l}\text { DEA- } \\
\text { Malmquist } \\
\text { index } 2018\end{array}$ & $\begin{array}{l}\text { DEA- } \\
\text { Malmquist } \\
\text { mean }\end{array}$ \\
\hline 1 & Guangfa Financial Credit A & 0.723 & 6.569 & 4.328 & 7.7605 & 4.845 \\
\hline 2 & Yifangda CSI 300 Index & 1.686 & 4.709 & 2.053 & 4.927 & 3.344 \\
\hline 3 & China Small and medium board ETF & 0.993 & 3.037 & 1.838 & 1.499 & 1.842 \\
\hline 4 & Haitong Shanghai periodic ETF & 0.728 & 1.869 & 1.151 & 1.5 & 1.312 \\
\hline 5 & Huabao Shanghai 180 value ETF & 1.064 & 1.284 & 1.195 & 1.47 & 1.253 \\
\hline 6 & Guangfa Zhongzheng 500 ETF & 0.706 & 1.862 & 0.874 & 1.536 & 1.245 \\
\hline 7 & Southern Shanghai 380 ETF link & 0.934 & 1.387 & 0.806 & 1.804 & 1.233 \\
\hline 8 & Jiaotong Bank Shenzheng 300 Value ETF & 0.898 & 1.127 & 0.999 & 1.786 & 1.203 \\
\hline 9 & Huaxia CSI 300 Index 300 ETF & 0.894 & 1.035 & 0.939 & 1.86 & 1.182 \\
\hline 10 & BaoYing 100 index strengthens & 0.833 & 1.622 & 1.074 & 1.13 & 1.165 \\
\hline 11 & Guolianan Shanghai commodities ETF & 0.64 & 1.606 & 0.836 & 1.349 & 1.108 \\
\hline 12 & Guolianan Shanghai commodities ETF Link & 0.765 & 1.332 & 0.966 & 1.252 & 1.079 \\
\hline 13 & Rich Country Tianrui powerful selection & 0.561 & 1.218 & 0.926 & 1.54 & 1.061 \\
\hline 14 & Msci China a-share index & 0.695 & 2 & 0.762 & 0.577 & 1.009 \\
\hline 15 & Haitong earnings growth & 0.518 & 2.088 & 0.263 & 0.863 & 0.933 \\
\hline 16 & Jiaotong Bank Balanced Mixture A & 0.969 & 0.842 & 0.474 & 1.44 & 0.931 \\
\hline 17 & Southern preferred VALUE A & 0.608 & 0.848 & 0.541 & 1.686 & 0.921 \\
\hline 18 & Cathay Pacific Taurus innovates and grows & 0.429 & 0.781 & 0.609 & 1.695 & 0.879 \\
\hline 19 & Huaxia Shanghai $50 \mathrm{ETF}$ & 0 & 1.094 & 1.03 & 0.997 & 0.78 \\
\hline 20 & Zhonghai consumption selection & 0.565 & 1.16 & 0.354 & 0.958 & 0.759 \\
\hline 21 & ICBC Credit Suisse 500 & 0.587 & 0.799 & 0.591 & 1.029 & 0.752 \\
\hline 22 & Xingquan Trend Investment & 1.268 & 0 & 0.624 & 1.09 & 0.746 \\
\hline 23 & Harvest Cycle Optimizing & 0.519 & 0.799 & 0.647 & 0.925 & 0.723 \\
\hline 24 & Core Advantage $\mathrm{C}$ of Baoying & 0.486 & 0.943 & 0.839 & 0.565 & 0.708 \\
\hline 25 & Yinhua Affluence Theme & 0.562 & 0.767 & 0.583 & 0.882 & 0.699 \\
\hline 26 & Nuoan growing & 0.319 & 0.977 & 0.641 & 0.797 & 0.684 \\
\hline
\end{tabular}




\begin{tabular}{|l|l|l|l|l|l|l|}
\hline 27 & Southern Strategy optimization & 0.546 & 0.632 & 0.548 & 0.936 & 0.666 \\
\hline 28 & Harvest Strategy Growth & 0.446 & 0.813 & 0.529 & 0.856 & 0.661 \\
\hline 29 & Tianfuhui Energy A & 0.464 & 0.83 & 0.793 & 0.542 & 0.657 \\
\hline 30 & China Selected Industries & 0.527 & 0.806 & 0.402 & 0.863 & 0.65 \\
\hline 31 & Guangfa small board growth & 0.562 & 0.593 & 0.496 & 0.892 & 0.636 \\
\hline 32 & Yi Fang da Ke Xiang & 0.521 & 0.666 & 0.465 & 0.85 & 0.626 \\
\hline 33 & Penghua securities a-share resources industry & 0.465 & 0.863 & 0.445 & 0.731 & 0.626 \\
\hline 34 & Xincheng Small and medium board & 0.368 & 0.643 & 0.623 & 0.612 & 0.562 \\
\hline 35 & Jingshun Great Wall growing & 0.584 & 0.365 & 0.729 & 0.556 & 0.559 \\
\hline 36 & Guotai Juxin Value Advantage A & 0.596 & 1.478 & 0 & 0 & 0.519 \\
\hline 37 & Jingshun Great Wall 300 & 0.583 & 0 & 0.555 & 0.864 & 0.501 \\
\hline 38 & Huitianfu Value Selection A & 0 & 0.721 & 0.653 & 0.585 & 0.49 \\
\hline 39 & UPVOTE Morgan China advantage & 0 & 0.581 & 0.546 & 0.702 & 0.457 \\
\hline 40 & Xinda Australia Bank upgrade & 0 & 0.594 & 0.705 & 0.529 & 0.457 \\
\hline 41 & Penghua value advantage & 0.571 & 0.831 & 0 & 0 & 0.351 \\
\hline
\end{tabular}

As we can see from the table 1, between 2015 and 2018 there were 3,18,7 and 18 funds respectively that were relatively efficient (DEA values greater than 1). In terms of four-year average DEA, there are 14 open-end funds in effect. The higher the fund efficiency value, the higher the Fund input-output ratio. It suggests that under the same input of management cost, risk and investment trend, higher efficiency value means the funds produce higher income output.

In the case of Rich Country Tianrui powerful selection (No.13) and Guolianan Shanghai commodities ETF (No.11), the weighted growth rate of net value of these two funds is 18th and 38th among the 41 funds respectively. If we only judge their performance from net value alone, these two funds are not in the lead. However, because of its low input such as income standard deviation and management fee, they reach a good efficiency value greater than 1 . On the other side, Yi Fang da Ke Xiang (No.32) and Yinhua Affluence theme (No.25) are ranked in the top 15 funds in terms of Sharp Index and weighted growth rate of net value. However, due to the large Beta value and the high change rate of fundshares, the efficiency values of these two funds are judged to be inefficient. After comparing the top 10 and bottom 10 funds, we find out that the top group has more advantages in terms of risk management, cost control, return rate and growth. They have a relative high average growth of net value while maintaining a low volatility, management costs and change rate of fundshares. These evidences suggest that in evaluation of fund performance, it is very narrow and misleading to only use return rate as one dimension measurement. It could negatively affect fund managers, investors and the development of market. A comprehensive fund performance evaluation should be multiple dimensions oriented to aggregate return, risk, liquidity, management and growth of funds.

Next, we compare our results on the top 10 funds in DEA model with the top 10 funds ranked in Sharpe index and the top 10 in Wind rating:

Table-2: Performance ranking comparison

\begin{tabular}{|l|l|l|l|l|l|}
\hline Name of Fund & $\begin{array}{l}\text { AVG } \\
\text { DEA }\end{array}$ & Name of Fund & $\begin{array}{l}\text { AVG } \\
\text { Sharp }\end{array}$ & Name of Fund & $\begin{array}{l}\text { WIND } \\
\text { RANK }\end{array}$ \\
\hline $\begin{array}{l}\text { Guangfa Financial Credit } \\
\text { A*** }\end{array}$ & 4.845 & $\begin{array}{l}\text { Guangfa Financial } \\
\text { Credit A*** }\end{array}$ & 0.126 & $\begin{array}{l}\text { Huaxia Shanghai 50 } \\
\text { ETF }\end{array}$ & 2.2 \\
\hline Yifangda CSI 300 Index & 3.344 & $\begin{array}{l}\text { Xingquan Trend } \\
\text { Investment }\end{array}$ & 0.058 & $\begin{array}{l}\text { Guangfa Financial } \\
\text { Credit A*** }\end{array}$ & 3.0 \\
\hline $\begin{array}{l}\text { China Small and medium } \\
\text { board ETF }\end{array}$ & 1.842 & $\begin{array}{l}\text { Huitianfu Value } \\
\text { Selection A }\end{array}$ & 0.056 & $\begin{array}{l}\text { UPVOTE Morgan } \\
\text { China advantage }\end{array}$ & 4.2 \\
\hline $\begin{array}{l}\text { Haitong Shanghai periodic } \\
\text { ETF }\end{array}$ & 1.312 & $\begin{array}{l}\text { Jingshun Great Wall } \\
\text { 300 Strengthen }\end{array}$ & 0.055 & $\begin{array}{l}\text { Guolianan Shanghai } \\
\text { commodities ETF }\end{array}$ & 5.6 \\
\hline $\begin{array}{l}\text { Huabao Shanghai 180 value } \\
\text { ETF*** }\end{array}$ & 1.253 & $\begin{array}{l}\text { Baoying 100 index } \\
\text { strengthens } * * *\end{array}$ & 0.054 & $\begin{array}{l}\text { Huabao Shanghai } 180 \\
\text { value ETF *** }\end{array}$ & 5.8 \\
\hline $\begin{array}{l}\text { Guangfa Zhongzheng 500 } \\
\text { ETF }\end{array}$ & 1.245 & $\begin{array}{l}\text { Huabao Shanghai 180 } \\
\text { value ETF*** }\end{array}$ & 0.053 & $\begin{array}{l}\text { BaoYing 100 index } \\
\text { strengthens*** }\end{array}$ & 7.2 \\
\hline $\begin{array}{l}\text { Southern Shanghai 380 ETF } \\
\text { link }\end{array}$ & 1.233 & $\begin{array}{l}\text { Yinhua Affluence } \\
\text { Theme }\end{array}$ & 0.049 & $\begin{array}{l}\text { Southern Shanghai } \\
\text { 380 ETF link }\end{array}$ & 7.2 \\
\hline $\begin{array}{l}\text { Jiaotong Bank Shenzheng 300 } \\
\text { Value ETF }\end{array}$ & 1.203 & $\begin{array}{l}\text { Guotai Juxin Value } \\
\text { Advantage A }\end{array}$ & 0.047 & $\begin{array}{l}\text { Haitong earnings } \\
\text { growth }\end{array}$ & 7.8 \\
\hline $\begin{array}{l}\text { Huaxia CSI 300 Index } \\
\text { ETF*** }\end{array}$ & 1.182 & $\begin{array}{l}\text { Huaxia Shanghai 50 } \\
\text { ETF }\end{array}$ & 0.044 & $\begin{array}{l}\text { Huaxia CSI 300 Index } \\
\text { 300 ETF*** }\end{array}$ & 9.0 \\
\hline $\begin{array}{l}\text { BaoYing 100 index } \\
\text { strengthens*** }\end{array}$ & 1.165 & $\begin{array}{l}\text { Huaxia CSI 300 } \\
\text { ETF*** }\end{array}$ & 0.040 & $\begin{array}{l}\text { Jiaotong Bank } \\
\text { Balanced Mixture A }\end{array}$ & 11.6 \\
\hline
\end{tabular}


The results show that a total of four funds ranked in top 10 in three ratings. It is because DEA model and Wind rating model still consider return rate as a main evaluation factor, as a result, they partially overlap with the traditional rating method. In these cases, funds' performance is relatively smooth or they are very efficient. The following three figures show four years' data of four funds under three evaluating method.

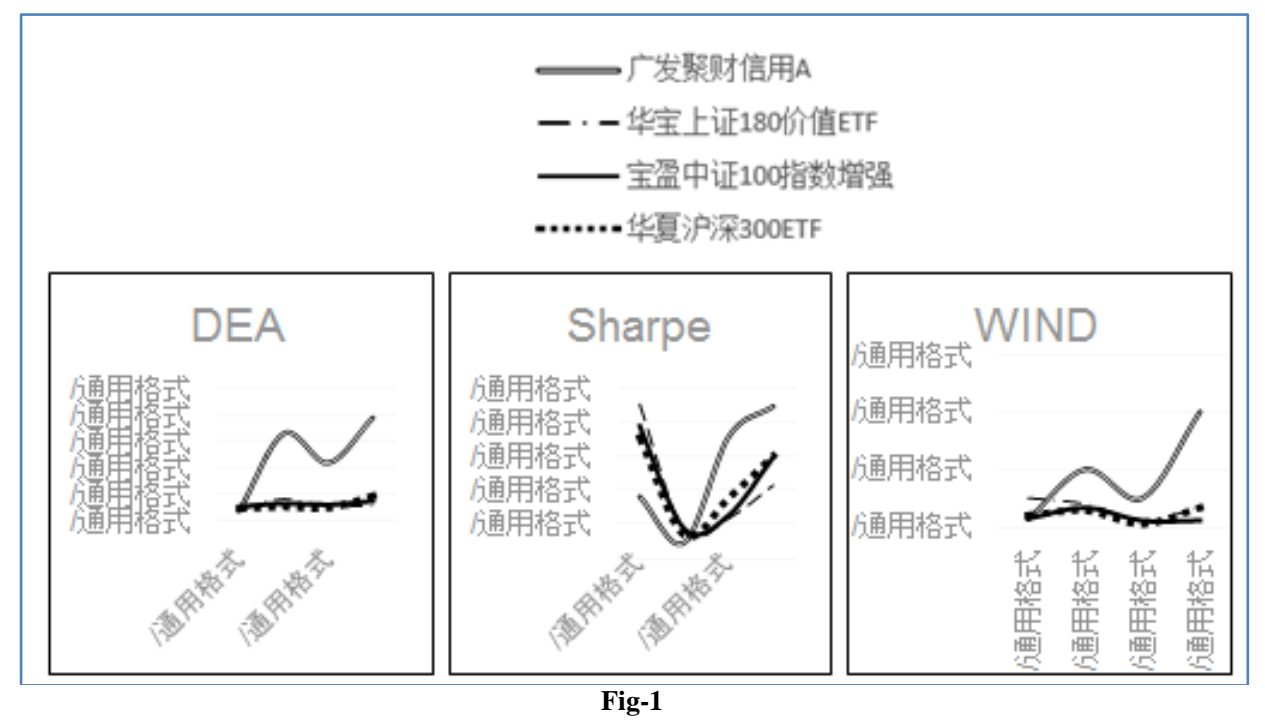

As we can see from the figure, DEA values behave similarly to the curve line of Wind. It could be that Wind evaluation use principal component analysis that also includes multiple dimension factors. As contrary, Sharpe Index is significantly different from the other two, especially between 2015 and 2016. Sharp index reflects the decline of returns that intrigued by a sharp drop in the stock market from its peak point in June 2015, while the other two measures show an upward trend of fund performance during the same period. This opposite conclusion happened again between 2016 and 2017. This mismatch of funds' performance between returns and efficiency has changed significantly after 2017. All three measures present a same upward trend of fund performance. It could be evidence suggests that the overall management of open-end Funds has made great progress. The investment market of fund is moving steadily into mature and the return rate and relative performance of Fund (Efficiency) are synchronizing.

\section{Analysis on factors influencing relative performance of funds}

The current research on the impact of factors on the relative performance of fund focus on type of fund, operation capacity, market performance and so on. Wu and Song [10] compared three funds with different investment styles and found that the stock funds have the highest average efficiency value but the lowest relative efficiency ratio, while the bond funds have the highest relative efficiency ratio and hybrid funds are in the middle. Meanwhile, they also found that the number of effective funds and fund operation time has a reverse relationship to certain degree. Hu, Wang and Fang [11] studied the open-end stock funds in China from 2007 to 2014. They found that the scale efficiency of passive funds was significantly higher than that of active funds, and the stability of Fund Management Team will increase the funds' technical efficiency. Wu [7] used traditional DEA model to analyze the relative performance of 271 active stock funds from 2012 to 2014. Using Tobit regression analysis, he found that the total value of fund and holding concentration are negatively correlated with the performance efficiency of active stock fund. He also found that the cost profit rate, selection ability and timing ability are positively correlated with the performance efficiency.

Based on prior literature, we examine the potential factors that affect the performance efficiency of open-end funds from both macrocosm and microcosm aspects. The relevant variables are summarized as follows: 


\section{Table-3: Summary of variables}

\begin{tabular}{|l|l|}
\hline Variable & Definition \\
\hline Ins_Prop & $\begin{array}{l}\text { Institutional investors' holding percentage, reflect the percentage of outstanding shares held by financial } \\
\text { institutions such as banks, securities companies in the open-end Fund. Usually, a higher institutional position } \\
\text { suggests less risk }\end{array}$ \\
\hline Fund_Size & The size of fund, an indicator of current value of fund \\
\hline Dividend & Total annual dividend of fund \\
\hline Stock_Pick & $\begin{array}{l}\text { The selection ability of fund manager, which is calculated by the excess return and the quadratic coefficient in } \\
\text { H-M model. It is used as a measure of fund manager's ability to predict the return of risk investment } \\
\text { comparing to risk-free interest rate }\end{array}$ \\
\hline Time_Select & $\begin{array}{l}\text { The timing ability of fund manager, which is calculated by the quadratic coefficient in T-M model. It reflects } \\
\text { the ability of fund manager to forecast the changing trend of stock }\end{array}$ \\
\hline Concentration & The degree of investment concentration, concentration degree of investment portfolio with strong correlation \\
\hline Info_Ratio & $\begin{array}{l}\text { Information ratio, a measure of risk return on investment portfolio relative to the market or industry } \\
\text { benchmark }\end{array}$ \\
\hline GDP_GR & $\begin{array}{l}\text { The change rate of Gross National Product (GNP) reflects the dynamic index of the change level of economic } \\
\text { development during evaluation period }\end{array}$ \\
\hline 7days_Interest & $\begin{array}{l}\text { he seven-day Interbank Offered Rate (HIBOR) represents the benchmark interest rate under current domestic } \\
\text { financial market environment. It reflects the degree of lending severities in the financial market }\end{array}$ \\
\hline NDF & $\begin{array}{l}\text { Non-deliverable forwards (NDF) are used to measure the expectation of RMB value in international financial } \\
\text { market }\end{array}$ \\
\hline Malmquist_DEA & The measure of fund performance efficiency \\
\hline
\end{tabular}

Table-4: Descriptive statistics

\begin{tabular}{|l|l|l|l|l|}
\hline Variable & Mean & Std.Dev. & Min & Max \\
\hline Ins_Prop & 28.469 & 31.665 & 0 & 99.315 \\
\hline Fund_Size & .119 & .122 & 0 & 1 \\
\hline Dividend & .071 & .178 & 0 & 1 \\
\hline Stock_Pick & .233 & .222 & 0 & 1 \\
\hline Time_Select & -2.828 & 6.629 & -25.397 & 13.386 \\
\hline Concentration & .453 & .574 & 0 & 2.725 \\
\hline Info_Ratio & .42 & 1.663 & -3.332 & 4.99 \\
\hline GDP_GR & .069 & .002 & .067 & .073 \\
\hline 7days_Interest & 3.278 & .779 & 2.428 & 4.46 \\
\hline NDF & 118.614 & 1.718 & 116.66 & 120.989 \\
\hline Mq_DEA & 1.144 & 1.385 & .286 & 7.7605 \\
\hline
\end{tabular}

As shown in table 4, the mean value of institutional holding is around $28 \%$. The mean value of timing ability is negative and its standard deviation is 6.629 indicating a largely distributed timing management. The mean value of concentration is around 0.45 and the mean value of information ratio is 0.42 suggesting a relative low risk.

Table-5: Correlation

\begin{tabular}{|c|c|c|c|c|c|c|c|c|c|c|}
\hline & $\begin{array}{c}\text { Ins_Prop } \\
\text { INS }\end{array}$ & FundSize & Div & Stock & Timet & Con & InfoRatio & $\begin{array}{l}\text { GDP } \\
\text { GDP }\end{array}$ & $7 \mathrm{dI}$ & CNY \\
\hline $\begin{array}{c}\text { Ins_Prop } \\
\text { INS }\end{array}$ & 1.000 & & & & & & & & & \\
\hline $\begin{array}{l}\text { Fund_Size } \\
\text { Fund }\end{array}$ & 0.165 & 1.000 & & & & & & & & \\
\hline $\begin{array}{l}\text { Dividend } \\
\text { Dividend }\end{array}$ & $\begin{array}{l}-0.280 \\
-0.280\end{array}$ & 0.399 & 1.000 & & & & & & & \\
\hline $\begin{array}{c}\text { Stock_Pick } \\
\text { Stock }\end{array}$ & 0.202 & 0.338 & $\begin{array}{r}-0.300 \\
-0.300 \\
\end{array}$ & 1.000 & & & & & & \\
\hline $\begin{array}{c}\text { Time_Select } \\
\text { Time }\end{array}$ & $\begin{array}{r}-0.364 \\
-0.364 \\
\end{array}$ & 0.094 & $\begin{array}{l}-0.155 \\
-0.155 \\
\end{array}$ & $\begin{array}{r}-0.418 \\
-0.418 \\
\end{array}$ & 1.000 & & & & & \\
\hline $\begin{array}{l}\text { Concentration } \\
\text { Concentration }\end{array}$ & 0.113 & 0.120 & 0.134 & 0.111 & 0.635 & 1.000 & & & & \\
\hline $\begin{array}{c}\text { Info_Ratio } \\
\text { Info } \\
\end{array}$ & 0.332 & 0.479 & 0.421 & $\begin{array}{r}-0.103 \\
-0.103 \\
\end{array}$ & 0.038 & 0.216 & 1.000 & & & \\
\hline $\begin{array}{c}\text { GDP_GR } \\
\text { GDP }\end{array}$ & 0.090 & 0.282 & 0.067 & 0.192 & 0.038 & 0.221 & 0.212 & 1.000 & & \\
\hline $\begin{array}{c}\text { 7days_Interest } \\
\text { 7days }\end{array}$ & 0.675 & 0.003 & $\begin{array}{l}-0.048 \\
-0.048\end{array}$ & 0.207 & 0.040 & 0.373 & $\begin{array}{r}-0.225 \\
-0.225\end{array}$ & 0.427 & 1.000 & \\
\hline $\begin{array}{l}\mathrm{NDF} \\
\mathrm{NDF}\end{array}$ & 0.001 & 0.019 & 0.209 & 0.082 & 0.048 & 0.048 & $\begin{array}{r}-0.044 \\
-0.044\end{array}$ & 0.441 & 0.167 & 1.000 \\
\hline
\end{tabular}


In correlation matrix, 7-day interbank offered rate has a high correlation with institutional holdings and investment concentration has a high correlation with timing ability. Others correlations are weak. It didn't show a strong evidence of Multicollinearity. In this paper, our data are unbalanced panel data that require OLS regression. After Breusch-Pagan and
Hausman test, we use the fixed effect model for regression analysis.

\section{Regression analysis}

In this paper, we use the following model to regress efficiency value of DEA-Malmquist on the potential influences of micro and macro factors:

$$
\begin{aligned}
& \text { Mq_DEA }_{i, t}=c+\beta_{1} \text { INS }_{i, t}+\beta_{2} \text { Fund_Size }_{i, t}+\beta_{3} \text { Fund_Size }_{i, t}{ }^{2}+\beta_{4} \text { Dividend }_{i, t}+\beta_{5} \text { Stock_Pick }_{i, t}+\beta_{6} \text { Time_Select }_{i, t}
\end{aligned}
$$

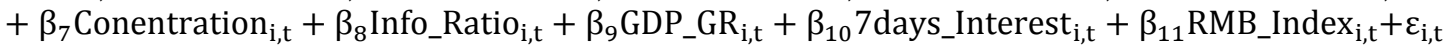

Since Grinblatt [12] found the inverted u curve between fund size and performance by adding time variable into the analysis and discover that the relationship between fund size and performance was not simple linear. Therefore, we introduce a quadratic term of fund size into the model.

Table-6: Regression results

\begin{tabular}{|c|c|c|}
\hline & (1) & $(2)$ \\
\hline & Fixed-effect model & Standard error of panel correction \\
\hline \multirow[t]{2}{*}{ Ins_Prop } & $0.00301 * *$ & 0.00427 \\
\hline & $(-1.39)$ & $(-4.61)$ \\
\hline \multirow[t]{2}{*}{ Fund_Size } & $10.11^{*}$ & $11.32 *$ \\
\hline & $(6.59)$ & $(21.61)$ \\
\hline \multirow[t]{2}{*}{ Fund_Size2 } & $-0.896 * * *$ & $-0.378 * *$ \\
\hline & $(10.83)$ & $(8.85)$ \\
\hline \multirow{2}{*}{ Dividend } & 0.00992 & -0.0416 \\
\hline & $(0.11)$ & $(-0.25)$ \\
\hline \multirow[t]{2}{*}{ Stock_Pick } & $0.424 * * *$ & $0.437 * * *$ \\
\hline & $(-2.81)$ & $(-5.01)$ \\
\hline \multirow[t]{2}{*}{ Time_Select } & -0.00222 & -0.00279 \\
\hline & $(-0.43)$ & $(-0.61)$ \\
\hline \multirow[t]{2}{*}{ Concentration } & $-0.0761 * * *$ & $-0.146^{* *}$ \\
\hline & $(-1.35)$ & $(-4.86)$ \\
\hline \multirow[t]{2}{*}{ Info_Ratio } & -0.00931 & $-0.0400 *$ \\
\hline & $(-0.52)$ & $(-1.95)$ \\
\hline \multirow[t]{2}{*}{ GDP_GR } & $311.7 * *$ & $359.4 * * *$ \\
\hline & $(2.23)$ & $(5.31)$ \\
\hline \multirow[t]{2}{*}{ 7D_Interest } & $-0.705 * *$ & $-0.821 * * *$ \\
\hline & $(-2.29)$ & $(-5.33)$ \\
\hline \multirow[t]{2}{*}{ NDF } & $-0.229 * *$ & $-0.276 * * *$ \\
\hline & $(-2.19)$ & $(-5.22)$ \\
\hline \multirow[t]{2}{*}{ _cons } & $8.063 * *$ & $10.64 * * *$ \\
\hline & $(2.10)$ & $(5.03)$ \\
\hline $\mathrm{N}$ & 205 & 205 \\
\hline R2 & 0.927 & 0.927 \\
\hline
\end{tabular}

Note: $\mathrm{p}^{*}, \mathrm{p}^{* *}, \mathrm{p}^{* * *}$ Represent significance at $10 \%, 5 \%$, and $1 \%$ level respectively, with $\mathrm{t}$ values in parentheses.

The above results show that Ins_Prop, Fund_Size, Fund_Size2, Centralization and Stk_Pick are significant in terms of micro influence factors. To be specific, there is a positive correlation between institutional holdings, fund size, the ability of selection and the relative performance of fund, while there is a negative correlation between the quadratic term of fund size, investment concentration and relative performance. These results suggest that a higher proportion of institutional investors increase the efficiency of open-end funds implementation. It could be that the cash flow from institutional investors in open-end funds is more stable, the higher proportion of institutional investment often represents more healthy liquidity and risk management. Yang [4] found that the ability of selection has higher impact on funds' performance in a bull market, lower in a bear market and the weakest in a volatile market. China's open-end fund market is gradually recovering after a sharp drop in 2014. Our paper found a positive correlation between fund managers' stock picking ability and efficiency performance from 2015 to 2018 that is consistent with prior research.

In addition, the regression data show that Fund size as an indicator of performance efficiency was positive and significant at $10 \%$ level, while the quadratic term Fund size was negative and has higher significance. From the growth of fund perspective, the increase of fund size will decrease investment cost due 
to scale effect. However, from the fund management perspective, after fund size reaches a certain level, the related risks in terms of portfolio management will become difficult that cause a burden to fund manager and a decline to fund performance. Therefore, the influence of fund size on fund performance is not a simple positive line, there may have an optimal range due to the coexist of fund growth and risk management.

The regression results also show that for every 1 percentage increase of investment concentration will cause a -0.0761 decrease on relative performance. It may be that investment concentration in industries will affect risk diversification. It leads to a higher correlation within portfolio and cause a negative impact on fund performance. However, Wei and Cheng [6] suggest that there may be an optimal interval between investment concentration and fund performance.

As for the macro factors, GDP has a positive impact on fund's efficiency performance. Being a macro-environment, GDP has a positive influence on fund management from both economic effect and investment willingness. Meanwhile, the negative significant coefficient of non-deliverable forwards reflects the correlation between China's securities market performance and international financial market to some extent. 7-day Interbank Offered Rate (HIBOR) also has a negative effect. The rise of HIBOR will cause an opposite change to securities prices and other investment products, consequently result in a decline in fund performance that consist of such portfolios.

\section{CONCLUSIONS}

In this paper, we use DEA-Malmquist model to establish a comprehensive evaluation measure on the relative performance of fund including fund liquidity, growth, and return and operation ability. We compare the differences between DEA value index and the traditional performance evaluation index. We further examine the macro and micro factors that may affect the relative performance efficiency of open-end funds. The major findings of this paper are summarized as follows:

First, the traditional method of performance evaluation is single dimension. Its measure doesn't consider some important factors such as the fund's growth, management ability, liquidity etc. It could lead to biased ranking results.

Second, using DEA value in regression, we also find an inverted $u$ curve between relative performance and fund size. It shows that there may be an optimal range of fund size to fund relative performance. This finding is helpful to the future management and evaluation of open-end funds.
Finally, the current investors of open-end funds are mainly small and medium-sized in China and the proportion of institutional investors is relatively low. Increase the institutional holdings in funds could bring a positive influence on relative performance of funds.

\section{REFERENCES}

1. Chen, Z., \& Lin, R.(2005). The main methods of fund performance evaluation based on Dea Model. Systems Engineering, 01:75-85+95.

2. Deng, C., \& Yuan, Q. (2007). Performance Evaluation of Securities Investment Funds Based on Dynamic DEA Model. Systems Engineering, 01:115-121.

3. Yang, D., \& Cai, J.(2008). Performance evaluation on open-end securities funds basedd on DEA method. Journal of the Anhui University, 2008, 32(2):128-135.

4. Yang, H., \& Tan, L.(2018). The influence of fund style timing ability on fund performance. Journal of Changchun University of Technology, 39(06):608612.

5. Xu, M., \& Zhang, B.(2009). Research on fund performance evaluation based on DEA. The practice and understanding of mathematics, 11; 29-34.

6. Liu, C., Dai, H., \& Bao, X.(2014). Performance analysis of Chinese Security Investment Funds based on DEA. Friends of Accountants; 29:120-122.

7. $\mathrm{Wu}, 1 .(2016)$. An analysis of the performance of active stock funds in China and its influencing factors based on DEA. Time Finance, 621(11):136-137.

8. Guo, S.(2011). An empirical study on performance evaluation of Chinese stock open-end Funds. Journal of the Yunnan University of Finance and Economics, 27(05):84-93.

9. Miguel, L. F. (2013). Democracia e representação: territórios em disputa. Editora Unesp.

10. ZHANG, J., \& LIU, J. (2009). Empirical Study on Performance Evaluation of Open-end Fund Based on Style Adjustment [J]. Journal of Wenzhou University (Natural Sciences), 1.

11. Hu, Y., Wang, C., \& Fang, Z. (2016). DEA efficiency decomposition and fund performance difference Attribution Research. Financial problems research, 11.

12. Bae, S. C., Min, J. H., \& Jung, S. (2011). Trading behavior, performance, and stock preference of foreigners, local institutions, and individual investors: Evidence from the Korean stock market. Asia- Pacific Journal of Financial Studies, 40(2), 199-239.

13. Charnes, A., Cooper, W. W., \& Rhodes, E. (1978). Measuring the efficiency of decision making units. European journal of operational research, 2(6), 429-444.

14. Treynor, J. (1965). How to rate management of investment funds.

15. Lee, H., Lee, C., Seol, H., \& Park, Y. (2008). On the R\&D priority setting in technology foresight: a DEA and ANP approach. International Journal of Innovation and Technology Management, 5(02), 201219. 